\title{
Inclusion of biofloc meal in tilapia diets and its effect o the structure of zooplankton community under biofloc system condition
}

\author{
Abd El-Naem F.A Zidan ${ }^{1}$, Hesham R.A. Mola ${ }^{2 *}$, Osama M. El-Husseiny ${ }^{1}$, Ashraf suloma ${ }^{1}$ \\ and Rania S Mabroke ${ }^{1}$ \\ 1- Fish Nutrition Laboratory (FNL), Animal Production Department, Faculty of Agriculture, \\ Cairo University, Giza 12613, Egypt \\ 2- National Institute of Oceanography and Fisheries (NIOF), Cairo 11516, Egypt \\ *Corresponding author: E. mail: hesham_reda06@yahoo.com
}

\begin{abstract}
The effect of diets formula on zooplankton community structure and quality subsequently and tilapia fingerling performance under biofloc system condition was examined using three isonitrogenous (30\% crud protein) and isocaloric $\left(4500 \mathrm{Kcal} \mathrm{kg}{ }^{-1}\right)$ diets; Control diet (C; Soybean based diet) $25 \%$ and $50 \%$ of soybean protein that were substituted by floc meal to form $\mathrm{FM}_{25}$ and $\mathrm{FM}_{50}$ diets, respectively. Protozoa was the most dominant group during the experiments especially ciliated protozoa which was dominated by Centropyxius sp. The control treatment showed the highest number for Centropyxius sp. (285000 org./L) subsequently the total zooplankton count (325667 org./L) and the best final body weight of tilapia. No significant difference was recorded between control and $\mathrm{FM}_{25}$ regarding tilapia final body weight. Despite the lowest different zooplankton group recorded their lowest numbers was under experimental condition of $\mathrm{FM}_{25}$ treatment, while the highest percentage of oligochaete worms (5.9\%) was noticed for such treatment. Significant positive correlation was found between Centropyxius sp. and Asplanchna sp. $(\mathrm{r}=0.95, \mathrm{P}=0.004)$ and ciliate protozoa with oligochaete worms $(\mathrm{r}=0.85$, $\mathrm{P}=0.03$ ). Rotifer population showed a significant correlation with dietary phosphorus and selenium content $(r=0.96, p=0.017)$. Also, the decreasing of rotifers in control $(9.11 \%)$ and $25 \%$ substitution biofloc experiment (17.3\%) was accompanied with the increasing of tilapia final weight to be 31 and $24 \mathrm{~g}$, respectively. This may attributed to the preference and consuming rotifers by fish. So, we conclude that diets formula affect the zooplankton community structure which subsequently showed their reflection on fish performance. More studies are needed to understand the relation among different zooplankton species as a step to control the biofloc meal quality by manipulating diets formula.
\end{abstract}

Key words: Biofloc system, Floc meal, Zooplankton, Tilapia.

\section{INTRODUCTION}

Studying the biofloc system and its condition are recently developed as seeking for economical feed stuffs and avoiding water losses and became an important in modern aquaculture. Biofloc is a biological system depends on activating heterotrophic bacteria to assimilate the excess ammonia in the pond and avoid aquatic organisms' toxicity. Chronic exposure to toxic un-ionized ammonia concentrations as low as $0.06 \mathrm{mgl}^{-1}$ cause gill and kidney damage, reduction in growth, possible brain malfunctioning, and reduction in the oxygen carrying capacity of the fish (Durborow et al., 1997). Anytime the un-ionized ammonia is higher than $0.05 \mathrm{mg} / \mathrm{L}$, the fish are being damaged; meanwhile level of $2.0 \mathrm{mgl}^{-1}$ is lethal (FrancisFloyd et al., 1990). Maintaining the carbone: nitrogen ratio around 1:10 or above by supplement 


\section{Abd El-Naem F.A Zidan et al.}

the culture media with carbon source guarantee the activation of the heterotrophic bacteria and maintaining a good water quality (Avnimelech, 1999).

Floc is the backbone unite of successive biofloc system and consists of other organisms than bacteria such as micro/macro invertebrates, filamentous organisms fungi, ciliates, flagellates, rotifers, nematodes, metazoans and detritus (Manan et al., 2016). Besides maintaining the water quality regarding ammonia levels, flocs act as secondary feed source for the aquatic organism (Hargreaves, 2013). Flocs could be grazed directly from pond column by fish or could be used as feedstuff if settled and added into fish diets. Floc meal quality and chemical composition depends largely on the zooplankton structure of the biofloc meal subsequently the nutrient composition of the fish diets. Manipulating the fish diets may result on improving the biofloc meal quality which means better fish feed utilization or high quality settled floc meal. So, in the present study, the effect of different dietary composition where biofloc meal alternated soybean in tialpia diets on the zooplankton community structure was studied. Meanwhile, an attempt was paid to understand the relation between media different nutrient, zooplankton community and relation among zooplankton groups.

\section{Design of the experiment}

\section{MATERIALS AND METHODS}

Zooplankton in substitution experiment was examined in duplicate, First experiment: control without any Substitution (control), second experiment: 25\% Substitution of soyabean $\left(\mathrm{FM}_{25}\right)$ and Third experiment: $50 \%$ Substitution of soyabean $\left(\mathrm{FM}_{50}\right)$. Tilapia fish fingerlings with average weight of $12.14 \mathrm{~g}$ were distributed in plastic tanks of 60L. Experimental tanks were supplied with well water and $8 \mathrm{~L}$ of prepared biofloc to initiate the system. Different tanks were supplied with carbon source to maintain $\mathrm{C}$ : $\mathrm{N}$ ratio of 1:10 to maintain active biofloc system. Biofloc of different treatments were settled down when total suspended solids reached 300mg/L to maintain the biofloc quality. Three isonitrogenous $30 \%$ crud protein and isocaloric $4500 \mathrm{Kcal}$ $\mathrm{kg}^{-1}$ diets were formulated; Control diet (C; Soybean meal as main protein source); $\mathrm{FM}_{25}(25 \%$ of soybean meal protein was replaced with floc meal; and $50 \%$ of soybean meal was replaced by biofloc meal, FM50) (Table 1). Floc meal was collected and dried during previous trail. Fish final weight and zooplankton count were detected at the end of the experiment which lasted for 56 days.

\section{Collection and analysis of zooplankton samples:}

Zooplankton samples were collected from different treatments in biofloc system using zooplankton net $(55 \mu \mathrm{m})$. Water was agitated well and $5 \mathrm{~L}$ of water sample was filtered by zooplankton net. The samples were fixed immediately using formaldehyde solution $(5 \%)$ and $2 \mathrm{ml}$ of Rose Bengal stain $(0.5 \%)$ was added after fixation.

The samples were examined under microscope. Three sub-samples (one $\mathrm{ml}$ for each) of the homogenized plankton samples were transferred to a counting cell and the different plankters were counted. Zooplankton population was then calculated as the number of individuals per Liter. The organisms were identified with magnification varying from 100X to 400X. Zooplankton were identified according to description and keys constructed by Edmondson (1966); Ruttner-Kolisko (1974); Shehata et al. (1998 a \& b) and Khalil (2000).

Number of zooplankton was calculated after examination for all the recorded species in each sample and expressed for organisms/litters depending on the following equation according to $($ APHA, 2005): No of organisms $/$ litter $=(\mathrm{N} \times \mathrm{D}) /(\mathrm{S} \times \mathrm{C})$

Where, 


\section{Inclusion of biofloc meal in tilapia diets and its effect o the structure of zooplankton community under biofloc system condition}

$\mathrm{N}=$ Number of organisms; $\mathrm{D}=$ volume of sample after filtration; $\mathrm{S}=$ Number of subsamples; $\mathrm{C}=$ Total volume of the collected sample.

Statistical analysis:

Correlation and regression analysis were established using EXCEL package (version 2007).

Formulation and proximate composition $\left(\mathrm{g} \mathrm{kg}^{-1}\right.$ dry weight basis) of experimental diets.

\begin{tabular}{|c|c|c|c|}
\hline Ingredients $(\mathrm{g} / \mathrm{kg})$ & control & $\mathrm{FM}_{25}$ & $\mathrm{FM}_{50}$ \\
\hline Fish meal $^{\mathrm{a}}$ & 190 & 190 & 190 \\
\hline Soybean meal $^{\mathrm{b}}$ & 360 & 260 & 190 \\
\hline Corn $^{c}$ & 389.4 & 329.4 & 239.4 \\
\hline Floc meal & 0 & 160 & 320 \\
\hline $\mathrm{oil}^{\mathrm{d}}$ & 40 & 40 & 40 \\
\hline Premix ${ }^{\mathrm{e}}$ & 10 & 10 & 10 \\
\hline Carboxy methyl cellulose $\mathrm{e}^{\mathrm{f}}$ & 10 & 10 & 10 \\
\hline Vitamin $C^{f}$ & 0.5 & 0.5 & 0.5 \\
\hline $\mathrm{BHT}^{\mathrm{f}}$ & 0.1 & 0.1 & 0.1 \\
\hline Total $(\mathrm{g})$ & 1000 & 1000 & 1000 \\
\hline \multicolumn{4}{|l|}{ Proximate composition } \\
\hline Moisture \% & 5.74 & 5.73 & 5.77 \\
\hline Crude protein $\%$ & 29.4 & 29.8 & 29.3 \\
\hline Lipid $\%^{\mathrm{G}}$ & 8.8 & 8.09 & 7.41 \\
\hline Ash \% & 6.39 & 8.40 & 10.26 \\
\hline \multicolumn{4}{|l|}{ Mineral } \\
\hline Calcium \% & 0.88 & 1.44 & 2.29 \\
\hline Magnesium \% & 0.16 & 0.18 & 0.29 \\
\hline Sodium \% & 0.20 & 0.26 & 0.73 \\
\hline Phosphor \% & 0.59 & 0.66 & 0.82 \\
\hline Potassium \% & 0.72 & 0.34 & 0.48 \\
\hline Selenium $\mathrm{mg} / \mathrm{kg}$ & ND & ND & 13.8 \\
\hline
\end{tabular}

${ }^{a}$ Local fish meal $(70 \% \mathrm{CP})$

${ }^{\mathrm{b}}$ Soy Factory, Food Technology Research Institute, Ministry of Agriculture, Giza, Egypt

Imported yellow corn from Argentina

${ }^{\mathrm{d}}$ Commercialfood-grade

${ }^{\mathrm{e}}$ Provides per kg of diet: retinyl acetate, 3,000 IU; cholecalciferol, 2,400 IU; all-rac- $\alpha$-tocopheryl acetate, $60 \mathrm{IU}$; menadione sodium bisulfite, $1.2 \mathrm{mg}$; ascorbic acid monophosphate (49\% ascorbic acid), $120 \mathrm{mg}$; cyanocobalamine, $0.024 \mathrm{mg}$; d-biotin, $0.168 \mathrm{mg}$; choline chloride, 1,200 mg; folic acid, $1.2 \mathrm{mg}$; niacin, 12 $\mathrm{mg}$; d-calcium pantothenate, $26 \mathrm{mg}$; pyridoxine. $\mathrm{HCl}, 6 \mathrm{mg}$; riboflavin, $7.2 \mathrm{mg}$; thiamin. $\mathrm{HCl}, 1.2 \mathrm{mg}$; sodium chloride $(\mathrm{NaCl}, 39 \% \mathrm{Na}, 61 \% \mathrm{Cl}), 3,077 \mathrm{mg}$; ferrous sulfate $\left(\mathrm{FeSO}_{4} \cdot 7 \mathrm{H}_{2} \mathrm{O}, 20 \% \mathrm{Fe}\right), 65 \mathrm{mg}$; manganese sulfate $\left(\mathrm{MnSO}_{4}, 36 \% \mathrm{Mn}\right), 89 \mathrm{mg}$; zinc sulfate $\left(\mathrm{ZnSO}_{4} \cdot 7 \mathrm{H}_{2} \mathrm{O}, 40 \% \mathrm{Zn}\right), 150 \mathrm{mg}$; copper sulfate $\left(\mathrm{CuSO}_{4} .5 \mathrm{H}_{2} \mathrm{O}, 25 \% \mathrm{Cu}\right), 28 \mathrm{mg}$; potassium iodide (KI, $\left.24 \% \mathrm{~K}, 76 \% \mathrm{I}\right), 11 \mathrm{mg}$; Celite AW521 (acid-washed diatomaceous earth silica), 1,000 mg Agri-Vet Co., Cairo, Egypt.

${ }^{\mathrm{f}}$ Algomhuria Pharmaceutical Chemical Co., Cairo, Egypt.

${ }^{\mathrm{G}}$ Calculated 


\section{Abd El-Naem F.A Zidan et al.}

\section{RESULTS AND DISCUSSION}

The highest tilapia final body weight and average number of total zooplankton were observed with the biofloc in control experiment without any substitution (325667 org. $\mathrm{l}^{-1}$ ), while the lowest value was observed for $\mathrm{FM}_{25}$ (Table 2 \& Figs. 1\&2). More inclusion of floc meal into tilapia diets leads to more accumulation of different minerals. Rotifers population number was noticed to be correlated with dietary content of phosphorus and selenium $(r=0.93, P=0.017)$. Rotifera showed the highest variety of species (6 species), however it recorded the lowest density among other zooplankton groups. The highest average number of total rotifer was observed with $\mathrm{FM}_{50}$ being 35666 org./L, while the lowest rotifers values was recorded with $\mathrm{FM}_{25}$ being 14666 organisms/L. Moderate rotifers number was recorded by the control (29667 organisms/L). In the same context Rotifera species showed different response with the different substitutions. The decreasing of rotifers in control $(9.11 \%)$ and $25 \%$ substitution $\left(\mathrm{FM}_{25}\right)$ biofloc experiment (17.3\%) was accompanied with the increasing of tilapia final weight being 31 and $24 \mathrm{~g}$, respectively. This may attributed to the preference and consumption of rotifers by fish due to their highest nutritional values. These finding agrees with that of Hegab et al. (2017).

The rotifer Lepadella ovalis and protozoan Centropyxius sp. were observed with a remarkable numbers under the different biofloc condition treatments. Lecane bulla and Lecane Closterocerca recorded the highest values with control being 21667 and 667 org./L, respectively. Philodina spp. numbers increased gradually with substitution being 1333, 2000 and 3666.7 org./L for control, $\mathrm{FM}_{25}$ and $\mathrm{FM}_{50}$, respectively. This indicated that, this species has the ability to grow and reproduce under the high suspended matters of biofloc system. Mola and Parveen (2014) stated that the rotifers Philodina spp. and Lecane spp. and the protozoan Centropyxius sp. can survive under stress of hard water conditions. Several significant positive correlations were recorded among different zooplankton species (Table 3). It seems that Asplanchna sp. numbers are significantly correlated with the presence of Centropyxius sp. $(\mathrm{r}=0.95, \mathrm{P}=0.004)(\mathrm{Fig} .3)$.

Table (2): Zooplankton in different experimental treatments.

\begin{tabular}{lcccccc}
\hline Species /Groups & \multicolumn{2}{c}{ Control } & \multicolumn{2}{c}{ FM $_{\mathbf{2 5}}$} & \multicolumn{2}{c}{ FM $_{\mathbf{5 0}}$} \\
\cline { 2 - 7 } Rotifera & Average & $\mathbf{\%}$ & Average & \% & Average & \% \\
\cline { 2 - 7 } Asplanchna sp. & 2000 & 0.61 & 0 & 0.0 & 0 & 0.0 \\
Lecane bulla & 21667 & 6.65 & 7333.3 & 8.6 & 29666.67 & 19.1 \\
L. Closterocerca & 667 & 0.20 & 333.3 & 0.4 & 333.3 & 0.2 \\
Lecane sp. & 0 & 0.00 & 3666.7 & 4.3 & 333.3 & 0.2 \\
Lepadella Ovalis & 4000 & 1.23 & 1333.3 & 1.6 & 1666.7 & 1.1 \\
Philodina sp. & 1333 & 0.41 & 2000 & 2.4 & 3666.7 & 2.4 \\
\hline Total & 29667 & 9.11 & 14666.67 & 17.3 & 35666.7 & 22.9 \\
\hline Protozoa & 1667 & 0.51 & 6000 & 7.1 & 1000 & 0.6 \\
Vorticella sp. & 285000 & 87.51 & 59000 & 69.4 & 113666.7 & 73.0 \\
Centropyxius sp. & 286667 & 88.02 & 65000 & 76.5 & 114666.7 & 73.7 \\
\hline Total protozoa & 9000 & 2.76 & 5000 & 5.9 & 5000 & 3.2 \\
\hline Oligochete worms & 333 & 0.10 & 333.3 & 0.4 & 333.3 & 0.2 \\
Nematoda & 325667 & 100.00 & 85000 & 100 & 155666.7 & 100 \\
\hline Total zooplankton & & & & & & \\
\hline
\end{tabular}


Inclusion of biofloc meal in tilapia diets and its effect o the structure of zooplankton community under biofloc system condition

Table (3): Correlation among different zooplankton groups and between rotifers and dietary phosphorus and selenium under condition of biofloc system.

\begin{tabular}{|lccc|}
\hline \multicolumn{1}{|c}{ Species } & Regression equation & $\mathrm{R}^{2}$ & Probability \\
\hline $\begin{array}{l}\text { Asplanchna sp. vs. } \\
\begin{array}{l}\text { Centropyxius sp. } \\
\text { Oligochete worms vs. }\end{array}\end{array}$ & $\mathrm{y}=0.007 \mathrm{x}-455.8$ & $\mathrm{R}^{2}=0.904$ & $\mathrm{P}=0.004$ \\
$\begin{array}{l}\text { L. Closterocerca } \\
\text { Oligochete worms vs. }\end{array}$ & $\mathrm{y}=8.700 \mathrm{x}+2466.6$ & $\mathrm{R}^{2}=0.690$ & $\mathrm{P}=0.04$ \\
$\begin{array}{l}\text { Centropyxius sp. } \\
\text { Total rotifers vs. } \\
\text { phosphorus and selenium }\end{array}$ & $\mathrm{y}=0.028 \mathrm{x}+2020.2$ & $\mathrm{R}^{2}=0.730$ & $\mathrm{P}=0.03$ \\
\hline
\end{tabular}

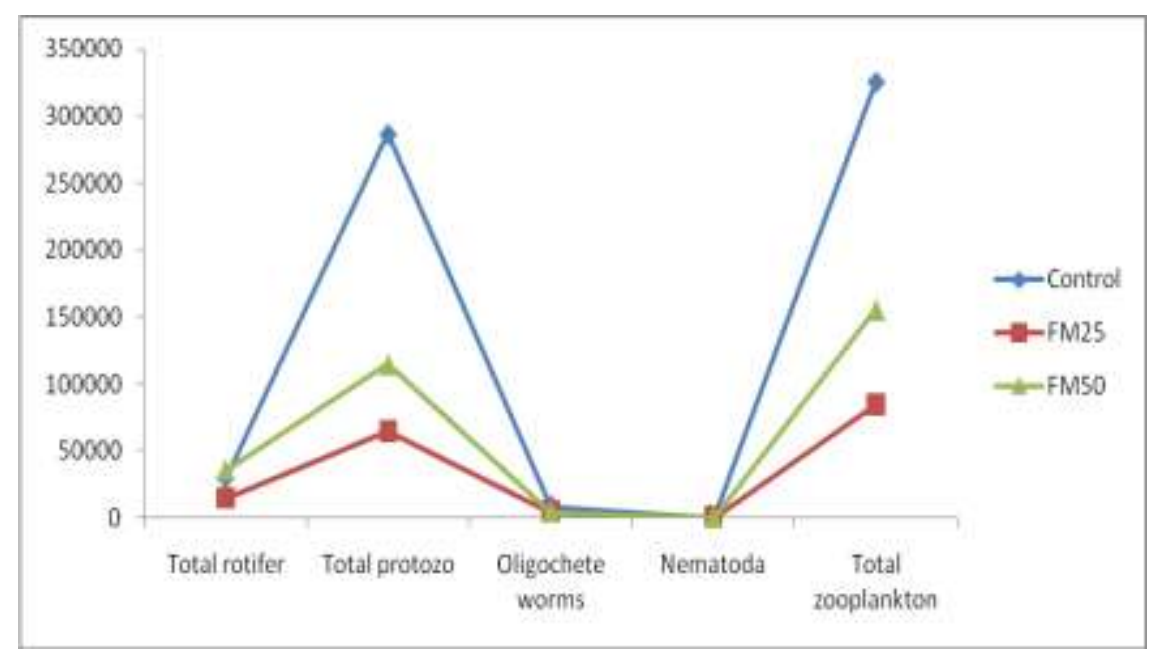

Fig.(1).Zooplankton community structure under different experimental treatment.

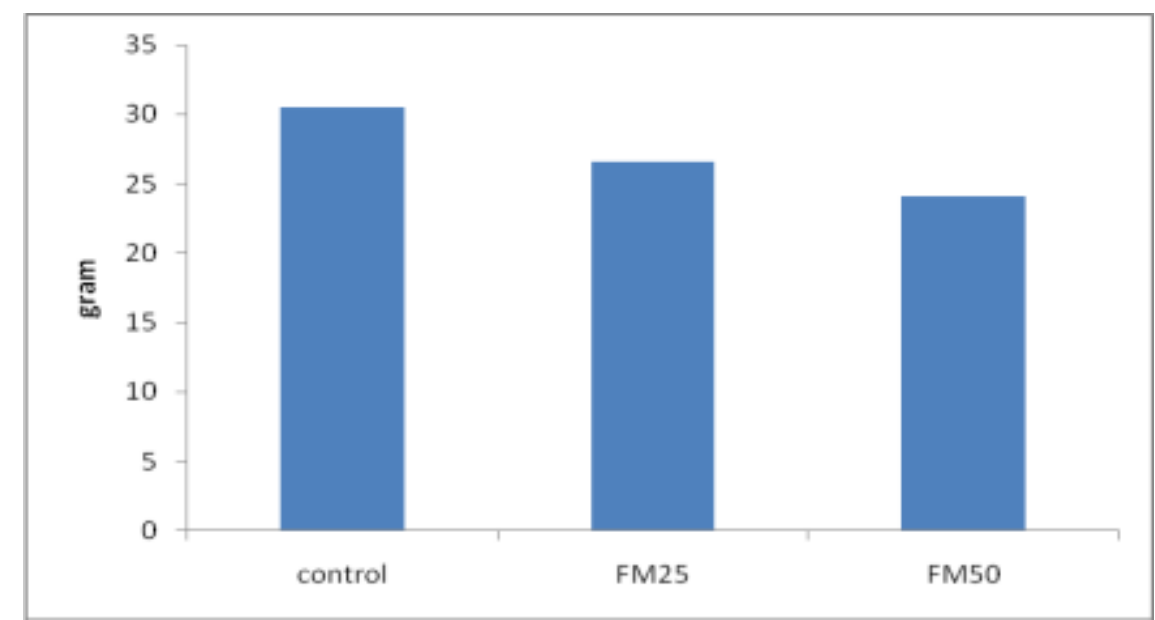

Fig. (2).The effect of different dietary formula on tilapia final body weight . 
Abd El-Naem F.A Zidan et al.

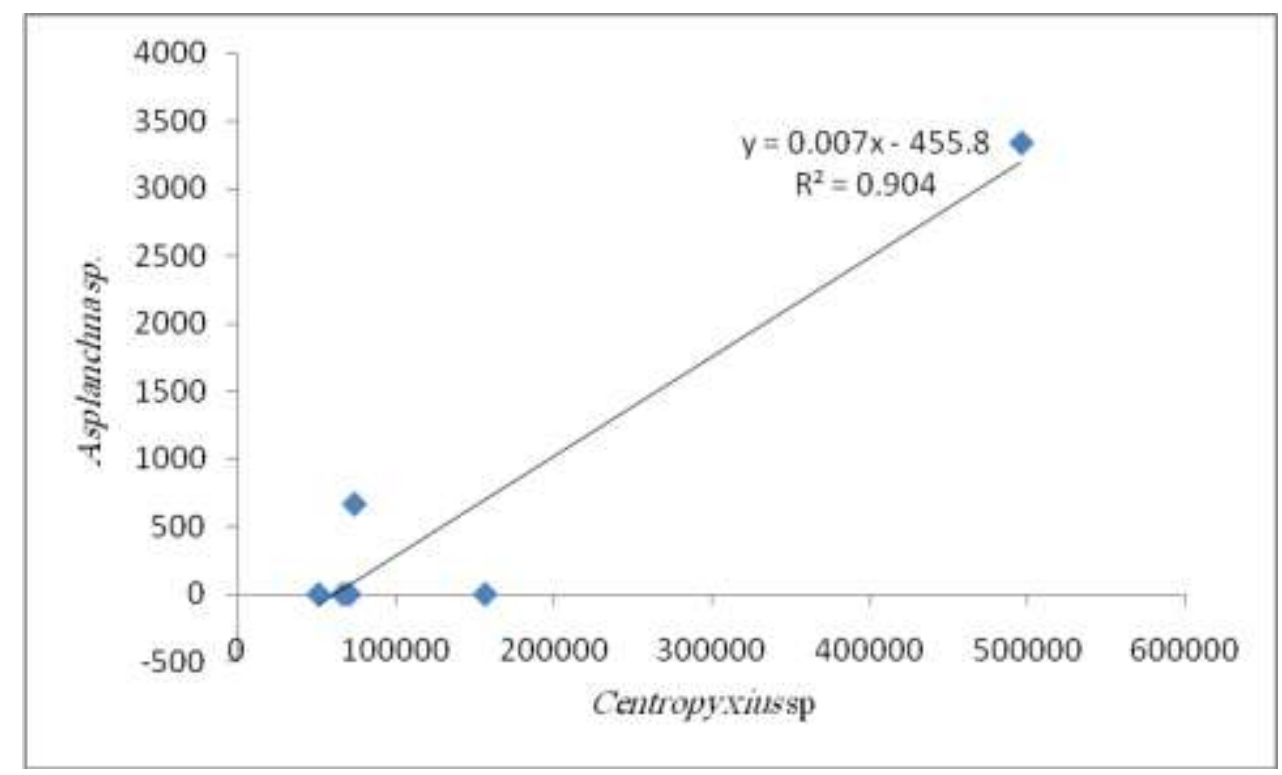

Fig. (3). Relationship between Asplanchna sp. and Centropyxius sp. population number.

Protozoa was the most dominant group during the experiments especially ciliates which was dominated by Centropyxius sp. and Vorticella sp (Fig., 6). The protozoan Vorticella sp. was observed with low number in most biofloc experiments. Ciliated protozoa recorded 286667 org./Lin the control and 65000 org./Lin $\mathrm{FM}_{25}$. Singh (2009) found that protozoa recorded large numbers in the presence of organic matters. The biofloc conditions stimulated the dominating of ciliated protozoa due to the availability of free bacteria (Madoni, 2017). Also, ciliate protozoa had the ability to consume free bacteria which improve water conditions (Gerardi et al., 1995). Meanwhile, Protozoa have effect on the bacterial growth as it release nutrient salts and other stimulatory substances which accelerate the use of carbon by the bacteria (Jurgens and Matz, 2002). Upon the previous, it seems that the increased number of ciliate protozoa have positive effect of biofloc condition subsequently tilapia growth performance where the control showed superiority over all treatments (Fig. 2).

Annelida were observed in the different experimental treatments (Fig. 7). It was represented by Oligochaete worms which recorded its highest numbers (9000 org./L) in control, while it recorded the numbers (5000 org./l) in the other biofloc substitutions of $\mathrm{FM}_{25}$ and $\mathrm{FM}_{50}$. Due to its large sizes in comparing to all the other Microinvertebrates, Oligochaete worms (the highest biomass) recorded remarkable percentage in $\mathrm{FM}_{25}$ experiment (substitution of 25\%) being $5.9 \%$. A positive correlation was recorded between oligochaete worms and the rotifer $L$. Closterocerca $(\mathrm{r}=0.83, \mathrm{p}=0.04)$. The Same trend was recorded between oligochaete worms and the Centropyxius sp. $(\mathrm{r}=0.85, \mathrm{P}=0.03)$ (Table $3 \&$ Figs. $4 \& 5)$. An oligochaete worm seems to have predatory activity against both $L$. Closterocerca and ciliate protozoa which may explain the low number and percentage of total zooplankton in $\mathrm{FM}_{25}$ treatment. On the other hand, no significant differences were recorded between control and $\mathrm{FM}_{25}$ regarding tilapia final body weight. This may be explained by the high percentage of the oligochaetes in $\mathrm{FM}_{25}$ treatment, where it considered as good palatable live feed source for aquatic organisms (Lietz,.. 1987). Eels 


\section{Inclusion of biofloc meal in tilapia diets and its effect o the structure of zooplankton community under biofloc system condition}

fed on Tubificidae (The most domiat oligochate worms in freshwater) as pre-weaning diet recorded high survival rates (El Hussieny et al., 2016). Alanine formed more than $23 \%$ and up to $41 \%$ of the total free amino acid of oligochete worms e.g. Limnodrillus spp. and Tubifx spp. (Graney et al., 1986). Saglio et al. (1990) mentioned that the combination of amino acids in the oligochate worm (Tubifex) recorded similar composition of that present in common carp fish. Pelegrí et al. (1995) observed that the presence of oligochaete worms is accompanied with the enhancement of biofloc conditions. Nematoda was the third dominant group after protozoa and oligochata and showed a remarkable number and recorded the highest percentage in $\mathrm{FM}_{25}$ treatment being $0.4 \%$ of the total zooplankton (Fig. 6).

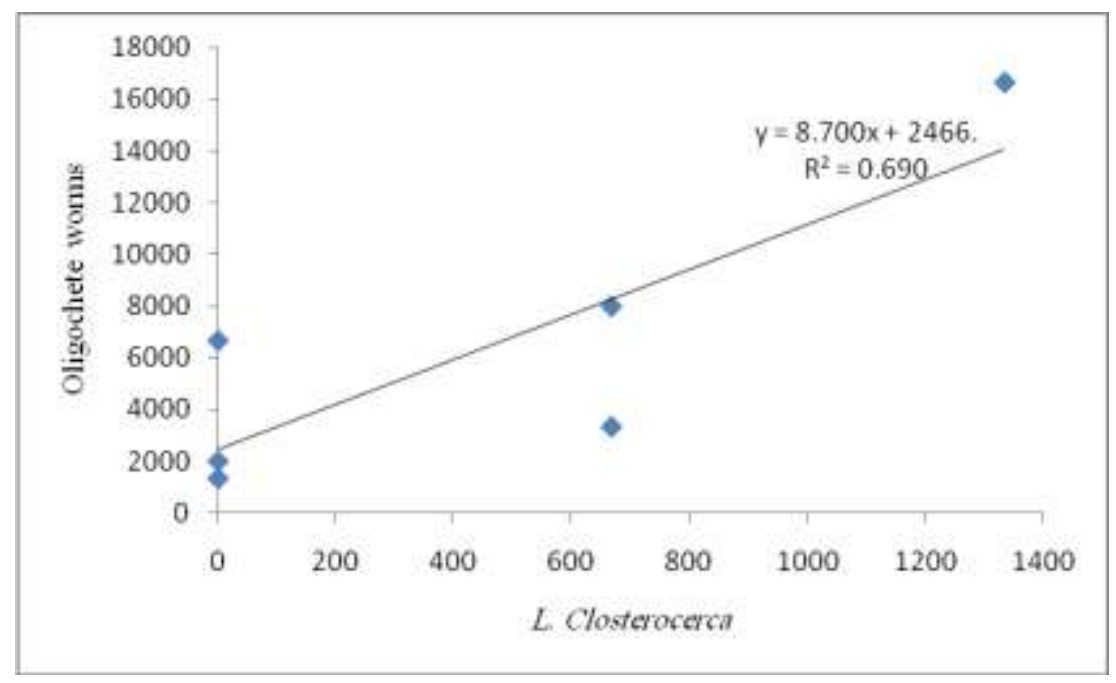

Fig. (4). Relationship between Oligochete worms and $L$. Closterocerca population number.

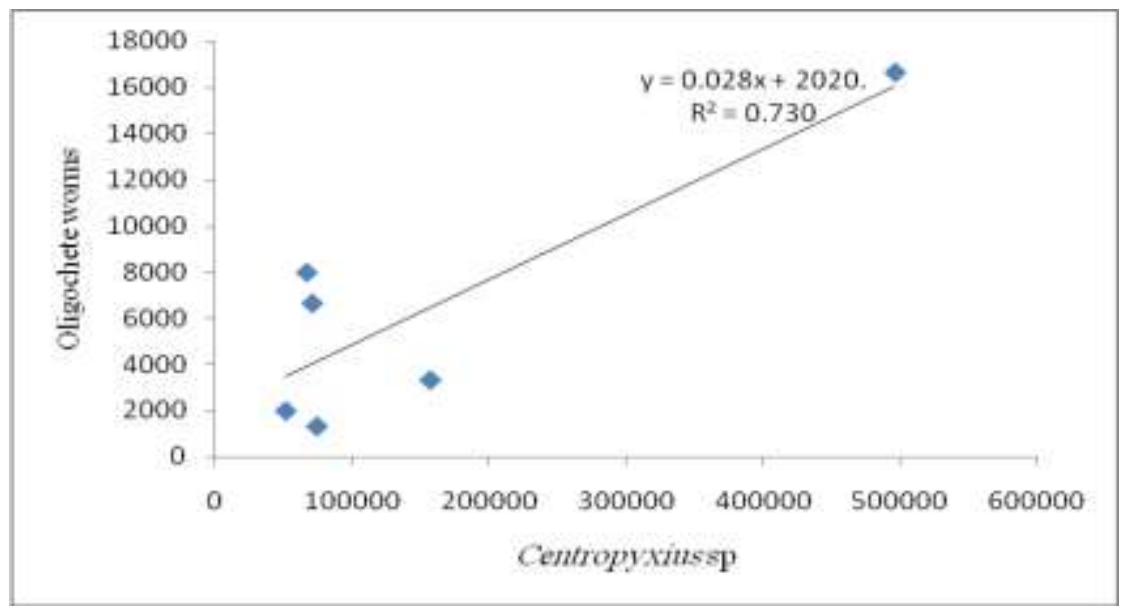

Fig. (5). Relationship between Oligochete worms and Centropyxius sp. population number. 


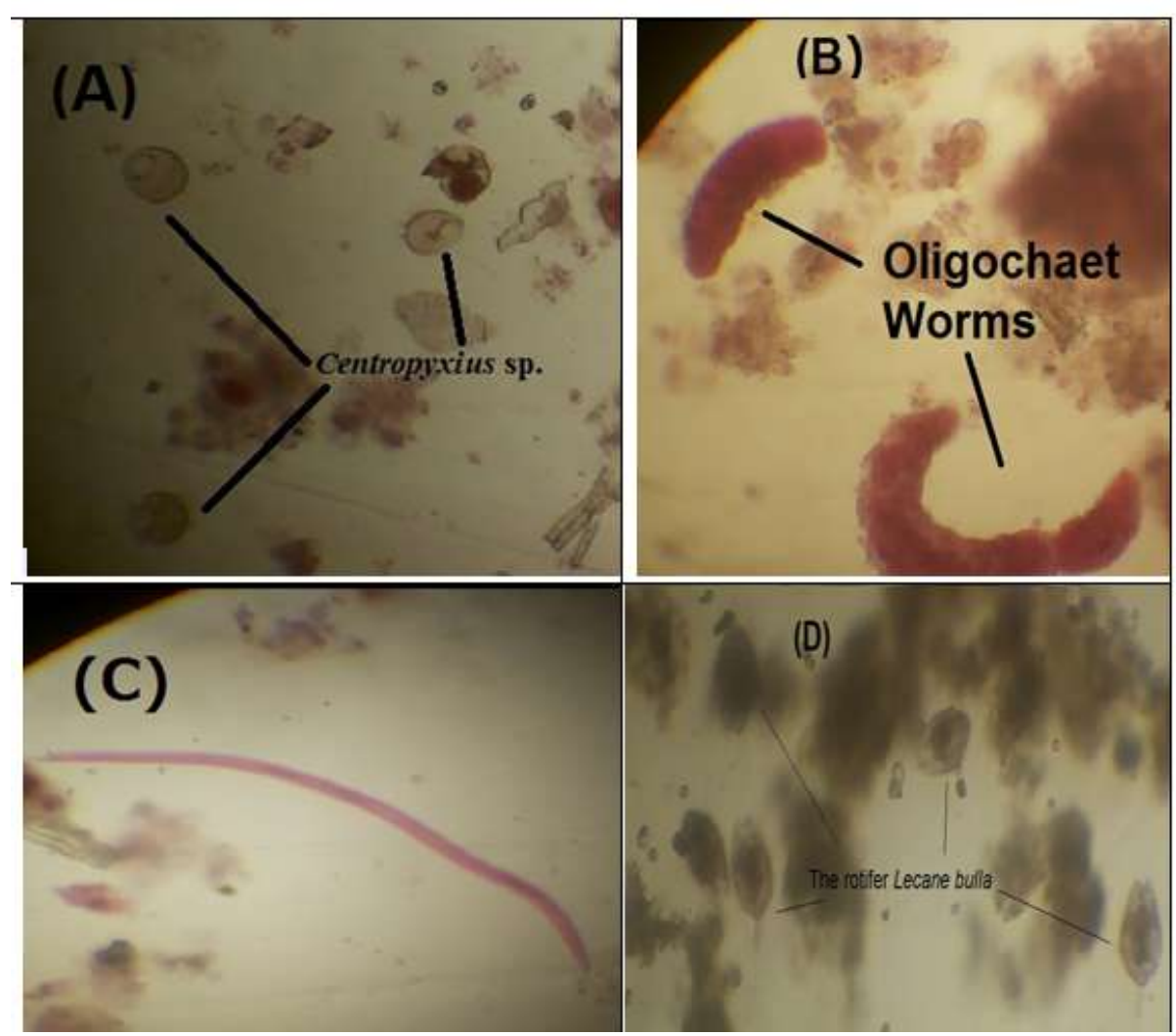

Fig. (6). Protozoan Centropyxius sp. (A), Oligochete worms (B), free Nematoda worm (C) and The rotifer Lecane bulla (D) which dominate the biofloc system in all tratments.

\section{Conclusion:}

It seems that the composition of fish diets affects on the zooplankton community structure. More inclusion of biofloc meal into tilapia diets resulted in more accumulation of different minerals with different balances among each other. Rotifers population number was correlated with dietary content of phosphorus and selenium. Also, the decreasing of rotifers in control $(9.11 \%)$ and $25 \%$ substitution biofloc experiment $(17.3 \%)$ is accompanied with the increasing of tilapia final weight being 31 and $24 \mathrm{gm}$ respectively. These relations may also reflect the zooplankton structure generally. The substitute of $25 \%$ percent of soybean in biofloc is better than $50 \%$ of substitution. So, fine tuning the dietary inputs into biofloc media may enriches the zooplankton community subsequently fish performance. Deep digging in the relation between different fish dietary formula and the zooplankton structure under biofloc condition is needed.

\section{Acknowledgments}

This work was funded by grants from the Science \& Technology Development Fund (STDF) in Egypt under tile of "Development of a biofloc technology for high intensive and organic production of tilapia, mullet and freshwater shrimp under desert conditions" no.5671. 


\section{Inclusion of biofloc meal in tilapia diets and its effect o the structure of zooplankton community under biofloc system condition}

\section{REFERENCES}

APHA (American Public Health Association) (2005). Standard Methods for Examination of Water and Wastewater. $21^{\text {st }}$ Ed. Standard Methods is a joint publication of the American Public Health Association (APHA), the American Water Works Association (AWWA), and the Water Environment Federation (WEF). Washington DC, USA.

Avnimelech, Y. (1999). Carbon/nitrogen ratio as a control element in aquaculture systems. . Aquaculture, 176: 227-235.

Bishai, H.M., Abdel Malek, S.A. and Khalil, M.T. (2000). Lake Nasser. Egyptian Environnemental Affairs Agency (EEAA production). National Biodiversity Unit. No. 11., Egypt , pp567.

Curds, C.R. (1973). The role of protozoa in the activated-sludge process. American Zoologist, 13 (1) : 161-169.

Durborow, R. M. ; Crosby, D.M., and Brunson, M.W. (1997). Ammonia in fish ponds. J. Fish. Res. Board of Canada, 32 : 2379-2383.

Edmondson, W.T. (1966). Freshwater Biology. $2^{\text {nd }}$ ed. John Wiley and Sons.Inc.New York \& London, $12248 \mathrm{pp}$.

El-Husseiny, O.M.; Goda, A.M.A.; Mabroke, R.S. and Souady M. (2014). Optimal stocking density for Nile tilapia, (Orechromis niloticus) within biofloc system. Annals of Agric. Sci., Moshtohor , 52(2): 197- 204.

Francis-Floyd, R.; Watson, C. ; Petty, D. and Pouder, D.B. (2009). Ammonia in aquatic systems. University of Florida IFAS Extension Publication\# FA-16.

Gerardi M.H.(1995). Wastewater Biology: The Microlife, A Special Publication, Water Environment Federation, $2^{\text {nd }}$ edition, Alexandria, Virginia .(c.f.), Motta, M.da, Pons, M.N., Vivier, H., Amaral, A.L., Ferreira, E.C., Roche, N., and Mota, M. (2001). The study of protozoa population in wastewater treatment plants by image analysis. Brazilian J.1. Chem. Engineering, 18(1): 103-111.

Graney, R.L.; T.J. Keilty and J.P. Giesy (1986). Free amino acid pools of five species of fresh water oligochaetes. Canad. J. Fish. and Aquat. Sci., 43: 600- 607.

Hargreaves, J.A. (2013). Biofloc Production Systems for Aquaculture. Southern regional aquaculture center. Publication No. 4503.

Hegab, M.H. (2010). Ecological studies on zooplankton and the relationships between them and food and feeding of some fish in Rosetta branch (River Nile), Egypt. M.Sc. Thesis. Zoology Dept, Fac. Sci., Al-Azhar Univ.

Hegab, M.H. ; Mola, H.R.A. ; Hassan, M.S. ; Abdel Hamid, M.S. and H.E. Elsaid (2017). Effect of two different carbon sources on Brachionus plicatilis culture. Egypt. J. Aquatic Res. (Accepted for publication).

Jürgens, K. and Matz, C. (2002). Predation as a shaping force for the phenotypic and genotypic composition of planktonic bacteria. Antonie van Leeuwenhoek, 81(1-4): 413-434.

Khalifa, N. (2000). Study on the impact of industrial wastes at Helwan on River Nile zooplankton. Ph.D. Thesis. Zoo. Dept. Fac. Sci. Cairo University, pp. 141.

Lietz, D.M. (1987). Potential for aquatic oligochaetes as live food in commercial aquaculture. In Aquatic Oligochaeta. Hydrobiologia, 155: 309-310.

Madoni, P. (2011). Protozoa in wastewater treatment processes: a mini review. Italian J. Zoology, 78(1):3-11. 


\section{Abd El-Naem F.A Zidan et al.}

Manan, H.; Moh, J.H.Z.; Kasan, N.A.; Suratman, S. and Ikhwanuddin, M. (2016). Identification of biofloc microscopic composition as the natural bioremediation in zero water exchange of Pacific white shrimp, Penaeus vannamei, culture in closed hatchery system. Applied Water Science, 1-10.

Mola, H.R.A. and Parveen, S. ( 2014). Effect of monsoon on zooplankton variations and environmental characteristics in a tropical fish pond at Aligarh, India. , Egypt. J. Aquat. Biol. \& Fish., 18 (3): 105-114.

Osama M. El-Husseiny, Ashraf M. A-S. Goda, Rania S. Mabroke and Mohamed Souady (2014). Optimal stocking density for Nile tilapia, (Orechromis niloticus) within biofloc system, Annals Agric. Sci., Moshtohor, 52(2) : 197- 204.

Parveen, S. and Mola, H.R.A. (2013). Comparison of physico-chemical parameters and zooplankton species diversity of two perennial ponds in Aligarh, Indian J. Environm. Biol., 34: 709-716.

Pelegrí, S.P. and Blackburn, T.H. (1995). Effects of Tubifex tubifex (Oligochaeta: Tubificidae) on $\mathrm{N}$-mineralization in freshwater sediments, measured with $15 \mathrm{~N}$ isotopes. Aquatic Microbial Ecol., 9(3):289-294.

Ruttner-Kolisko, A. (1974). Planktonic rotifers. Biology and Taxonomy. Binnenge Wasser. Suppl., 26:146pp.

Saglio P.; B., Fauconneau and J.M., Blanc (1990). Orientation of carp, Cyprinm carpio L., to free amino acids from Tubifex extract in an olfactometer. J. Fish Biol., 37: 887-898.

Shehata, K.K; Shehata, S.M.A.; Hussien, M.M. and Abd El-Mageed, A. (1996a). Taxonomical and ecological studies on some Zooplankton species; Ciliata, Rhizopoda, Turbellaria and Crustaceae of high Dam Lake. Egypt. J. Aquat. Biol. \& Fish., 2 (1): 37-63.

Shehata, S.M.A.; Shehata, K.K; Hussien, M.M. and Abd El-Mageed, A. (1996). Ecological aspects of high Dam Lake with special reference to the seasonal distribution of the fresh water copepods. Al-Azhar Bull. Sci., 7 (1): 731-761.

Singh, K. (2009). Studies on the impact assessment of post Lake Management operations in Upper Lake with special reference to zooplankton. $\mathrm{PhD}$ Thesis, Department of Limnology, Barkatullah University, Bhopal, India, pp.146. 


\title{
Inclusion of biofloc meal in tilapia diets and its effect o the structure of zooplankton community under biofloc system condition
}

\section{ادراج مسحوق البروتين الميكروبي في النظام الغذائي للبطي وتاثيرها علي المحتوي الكلي من الهائمات الحيوانية تحت نظام البيوفلوك}

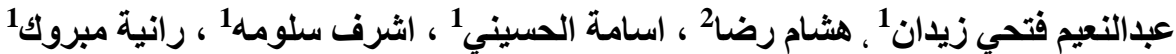

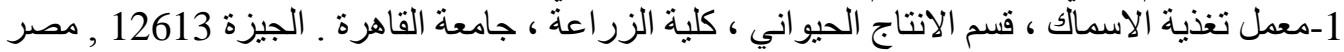

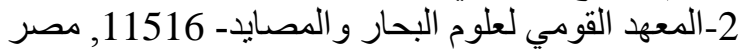

\footnotetext{
المستخلص

تم در اسة تأثير نركيب العليقة الغذائية على المحتوي الكلي من الهائمات الحيو انية ونو عيتها، ونم الكثف عن الاداء

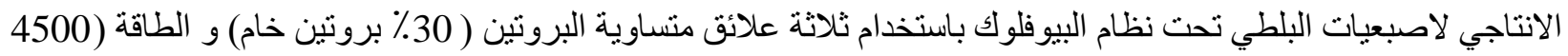

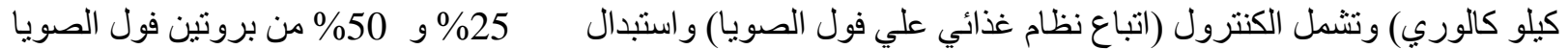

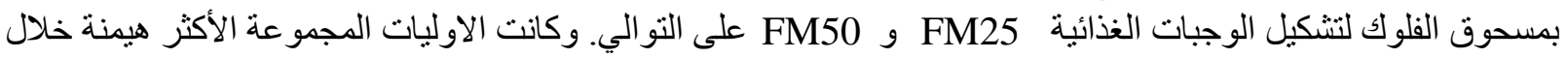

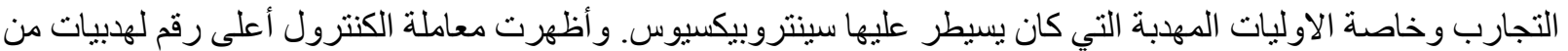

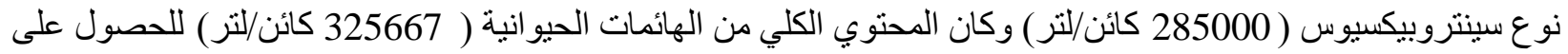

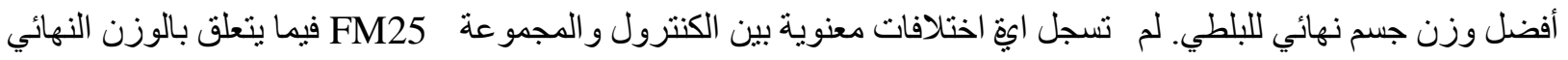

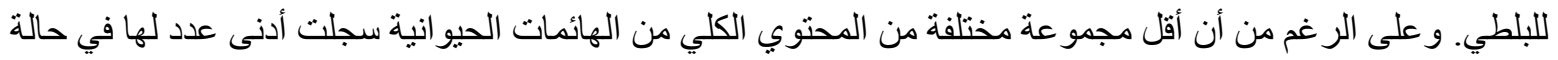

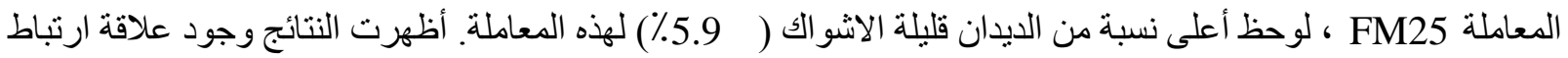

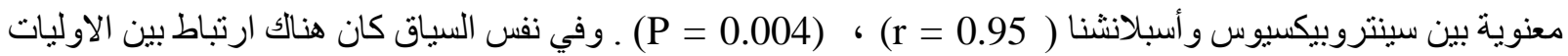
الحيو انية و الديدان قليلة الاشو الك (

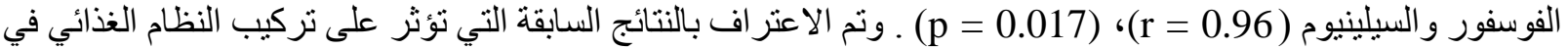

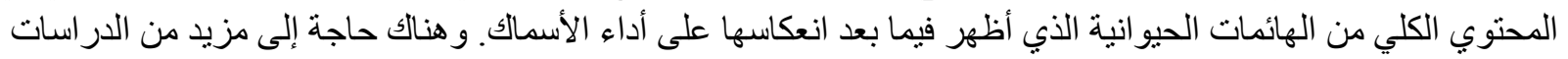
لفهم العلاقة بين انواع العو الق الحيو انية المختلفة كخطوة للسيطرة على جودة مسحوق الفلوك من خلال التغير فى النظام 